〔72〕高分解能核磁気共鳴吸収によるポリアクリロ ニトリルの立体規則性の研究

(1965 年 12 月 20 日受理)

村野政生* . 山寺 礼三*

\begin{abstract}
要 旨 重合条件の異なる 16 種類のポリアクリロニトリル(PAN), およびポリー $\alpha$-重水素化アクリロ ニトリル $\left(\mathrm{PAN}-\alpha d_{1}\right)$ について, NaCNS の重水溶液を溶媒として高分解能核磁気共鳴スペクトルを測定し た。PAN のメチレン基プロトンの共鳴スペクトルは Syndiotactic 部分と Isotactic 部分とによる二つの Triplet の重なりと考えられ, それらの面積強度を別々に算出することによって各試料の立体規則性を推定す ることができた。ラジカル重合および常温のアニオン重合でつくった PAN は約 75\% の Syndiotactic 部 分を含み, 低温アニオン重合, 固相放射線重合, $\mathrm{Mg}$ 分子線法および尿素包接化合物の放射線重合により得た PAN では Syndiotactic 部分がやや少ないが，いずれも顕著な立体特異性は示していない。
\end{abstract}

\section{1. 緒言}

ポリアクリロニトリル $(\mathrm{PAN})$ の分子構造に関しては, これまで, X 線回折, 赤外線吸収などによって,いくつ かの研究がなされたが，その立体規則性についてはまだ 詳細な議論を行なうに至っていない。PAN は明確な X 線回折図を示さないが、Bohn らばその X 線図から, PANは長さ与向に規則性がなく, 無秩序に折れ曲がった 構造を有することを推定している。また, Lindenmeyer $ら^{2)}$ は, PAN の単結晶の電子線回折を測定し, 分子鎖 が無秩序な Conformation からできていると推論して いる。山寺ら ${ }^{3)}$ (5) は, PAN および重水素化 PAN の赤 外線吸収スペクトルの実測波数とSyndiotactic, 平面ジ グザグ鎖を仮定して計算した基準振動の計算結果が，か なり良い一致を示寸ことから，PAN はこれに近い構造 を含むことを予想しているが，詳細な議論は X 線回折 や, 核磁気共鳴吸収(NMR) の研究にまたなけ机ばなら ないと述べている。最近, Chiang ${ }^{6)}$ は, 重合条件の異な る種々の PAN の結晶化温度を测定し, 結晶化温度の 差は, PAN の立体規則性の差に基くものであると推定 している。

高分子の分子構造の研究に扔いて, 高分解能 NMR の測定がきわめて重要であり7), すでにポリメチルメタク リレート,ポリ塩化ビニル (PVC), ポリビニルアルコー ル，その他の高分子について立体規則度の測定が行なわ れてきているが, PAN については従来報告がなかった。

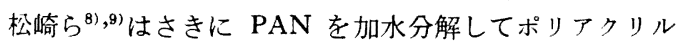
酸とし,さらにポリアクリル酸メチルにかえてその NMR スペクトルからもとの PAN の立体規則性を推定 した ${ }^{8)}$ が，その後の研究においてPANの加水分解の際, $\alpha$ 位の水素が置換してラセミ化が起こることを報告して

* 東洋紡績株式会社繊維技術研究所(滋賀県滋賀郡堅田町本堅 田 1300)
いる ${ }^{9)}$ 。筆者らは, 前報 ${ }^{10)} に$ に扎て, $\mathrm{NaCNS}$ の重水溶 液を溶媒として $100^{\circ} \mathrm{C} て ゙ \mathrm{PAN} の \mathrm{NMR}$ を直接測定 し,このスペクトルのメチレン基共鳴は PVC と同様な 方法で解析が 可能であり，これに基いて PAN の立体 規則性についての議論ができることを報告した。本報告 では, 重合条件の異なる種々の PAN について NMR スペクトルを測定し，メチレン基共鳴の形から大約の立 体規則度を求めた結果について述べる。

\section{2. 実験}

\section{1 重 合}

アクリロニトリル (AN) および $\alpha$ 重水素化アクリロ ニトリル $\left(\mathrm{AN}-\alpha d_{1}\right)$ の重合条件を Table 1 に示す。

\subsection{NMR スペクトルの测定}

溶媒として $\mathrm{NaCNS}$ の $50^{\circ}, \mathrm{D}_{2} \mathrm{O}$ 溶液を用い, PAN を約 $5 \%$ の䟴度に溶かして $120^{\circ} \mathrm{C}$ で測定した。

NMR スペクトルはV Varian A-60 型 NMR スペク トロメーターを用いて測定した。

なお, Polymer $A_{1}$ については, 溶媒として重水素 化ジメチルスルホキサイド $\left(\mathrm{CD}_{3}\right)_{2} \mathrm{SO}$ を用い $160^{\circ} \mathrm{C}$, $60 \mathrm{Mc}$ での測定, および $\mathrm{NaCNS}-\mathrm{D}_{2} \mathrm{O}$ 溶液を溶媒と して用い $120^{\circ} \mathrm{C}, 100 \mathrm{Mc}$ での測定も行なった。100 Mc のスペクトルの测定には, 日本電子 $4 \mathrm{H}-100$ 型 NMR スペクトロメーター*1を用いた。また， $100 \mathrm{Mc} の$ 測定 において、サイドバンド法に上る二重共鳴法を用いてメ チン基からデカップルしたメチレン基の共鳴吸収を測定 した。

\section{3. 実験 結 果}

レドックス触媒により重合した PAN (Polymer $\left.A_{1}\right)$ の NMR スペクトルをFig. 1 に示寸。 $\tau=6.2 \mathrm{ppm}$ 付近の ピークは $\mathrm{D}_{2} \mathrm{O}$ 中に含まれる $\mathrm{H}_{2} \mathrm{O}$ によるものである。

\footnotetext{
*1 大阪大学基礎工学部設圈。
} 
Table 1. Polymerization of acrylonitrile and $\alpha$-deuteroacrylonitrile.

\begin{tabular}{|c|c|c|c|c|c|c|c|}
\hline & & & & & & & \\
\hline Polymer & $\begin{array}{l}\text { Mono- } \\
\text { mer }\end{array}$ & Polymerization & Catalyst & Solvent & $\begin{array}{l}\text { Tempera- } \\
\text { ture }\left({ }^{\circ} \mathrm{C}\right)\end{array}$ & $\begin{array}{c}\mathrm{Re}- \\
\text { ference }\end{array}$ & Figure \\
\hline $\mathrm{A}_{1}{ }^{*}$ & AN & Radical & $\mathrm{NaHSO}_{8}+\mathrm{K}_{2} \mathrm{~S}_{2} \mathrm{O}_{8}$ & $\mathrm{H}_{2} \mathrm{O}$ & 60 & & $1,11,12,14-\mathrm{a}$ \\
\hline $\mathrm{A}_{2}$ & AN & Radical & $\mathrm{NaHSO}_{3}+\mathrm{K}_{2} \mathrm{~S}_{2} \mathrm{O}_{8}$ & $\mathrm{H}_{2} \mathrm{O}$ & 60 & & 2 \\
\hline B & AN & Radical & Azoisobutyronitrile & DMF & 65 & & \\
\hline $\mathrm{C}$ & $\mathrm{AN}-\alpha d_{1}$ & Radical & Azoisobutyronitrile & Benzene & 65 & & 9,10 \\
\hline $\mathrm{D}$ & AN & Anionic & Li-naphthalene & DMF & 20 & & \\
\hline $\mathrm{E}$ & $\mathrm{AN}$ & Anionic & $\mathrm{NaCN}$ & $\mathrm{DMF}$ & 20 & & 3 \\
\hline $\mathbf{F}$ & AN & Anionic & $\mathrm{LiAlH}_{4}$ & Ethyl ether & 20 & & 4 \\
\hline G & $\mathrm{AN}$ & Anionic & $\mathrm{Na}$-naphthalene & $n$-Hexane & 0 & & \\
\hline $\mathrm{H}$ & $\mathrm{AN}$ & Anionic & Li-naphthalene & Ethyl ether & -78 & & \\
\hline I & $\mathrm{AN}$ & Anionic & $\mathrm{Na}$-naphthalene & DMF & -78 & & \\
\hline $\mathbf{J}$ & AN & Anionic & $n$-Butyl $\mathrm{Li}$ & DMF & -78 & & 5 \\
\hline $\mathrm{K}$ & $\mathrm{AN}$ & Anionic & $\mathrm{Mg}$ & - & - & 11) & 6 \\
\hline $\mathrm{L}$ & AN & Irradiation in solid state & $\gamma$-ray & (Bulk) & -198 & 12) & 7 \\
\hline $\mathbf{M}$ & $\mathrm{AN}-\alpha d_{1}$ & Irradiation in solid state & $\gamma$-ray & (Bulk) & -198 & & \\
\hline $\mathbf{N}$ & AN & Irradiation on urea canal & $\gamma$-ray & - & -78 & 13), 14) & 8 \\
\hline $\mathrm{O}$ & $\mathrm{AN}-\alpha d_{1}$ & Irradiation on urea canal & $\gamma$-ray & - & -78 & & \\
\hline $\mathbf{P}$ & AN & Irradiation on urea canal & $\gamma$-ray & - & -198 & & \\
\hline
\end{tabular}

* Molecular weight of $A_{1}$ is lower than that of $A_{2}$.

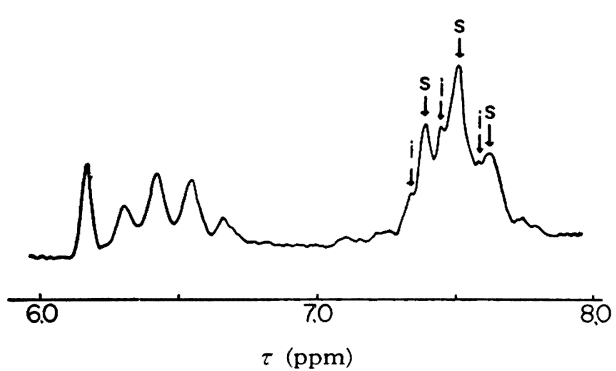

Fig. 1. NMR spectrum of PAN prepared with redox catalyst (Polymer $\mathrm{A}_{1}$ ) at $60 \mathrm{Mc}$.

種々の重合方法によって得られた PAN (Polymer $\mathrm{A}_{2}$, $\mathrm{E}, \mathrm{F}, \mathrm{J}, \mathrm{K}, \mathrm{L}$ および N) のメチレン基プロトンのス ペクトルを Fig. 2〜 Fig. 8 に示す。

Fig. 9 および Fig. 10 はアゾイソブチロニトリル (AIBN) により重合したポリ $-\alpha$ 重水素化アクリロニト リル $\left(\mathrm{PAN}-\alpha d_{1}\right)$ の $60 \mathrm{Mc}$ および $100 \mathrm{Mc}$ の NMR スペクトルを示す。

Fig. 14-a はレドックス触媒により重合したPAN (Polymer $\mathrm{A}_{1}$ ) について $100 \mathrm{Mc}$ で測定した $\mathrm{CH}_{2}$ 基プ ロトンのスペクトルであり, Fig. 11 は同じく $100 \mathrm{Mc}$ で $\mathrm{CH}$ 基プロトンからデカップルした $\mathrm{CH}_{2}$ 基プロト ンのスペクトルである。

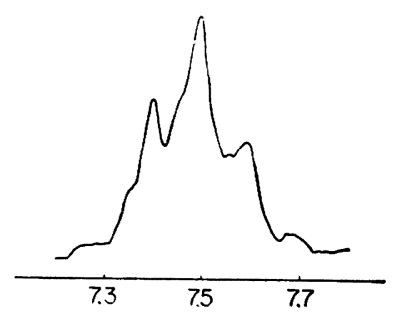

- (ppm)

Fig. 2. Methylenic proton resonance spectrum of PAN prepared with redox catalyst (Polymer $\mathrm{A}_{2}$ ) at $60 \mathrm{Mc}$.

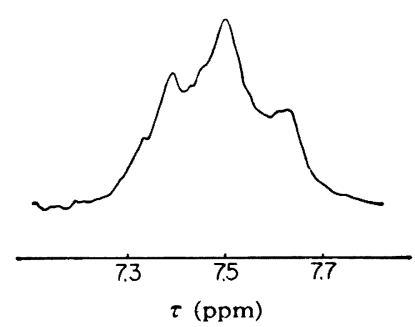

Fig. 3. Methylenic proton resonance spectrum of PAN prepared with anionic catalyst (Polymer E) at $60 \mathrm{Mc}$. 


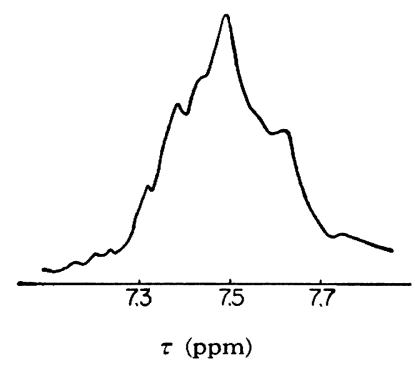

Fig. 4. Methylenic proton resonance spectrum of PAN prepared with anionic catalyst (Polymer F) at $60 \mathrm{Mc}$.

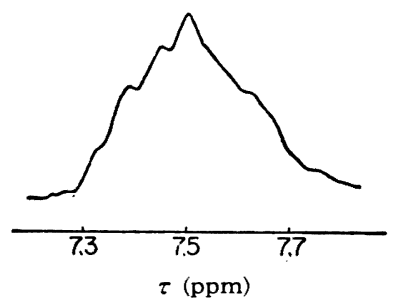

Fig. 5. Methylenic proton resonance spectrum of PAN prepared with anionic catalyst (Polymer J) at $60 \mathrm{Mc}$.

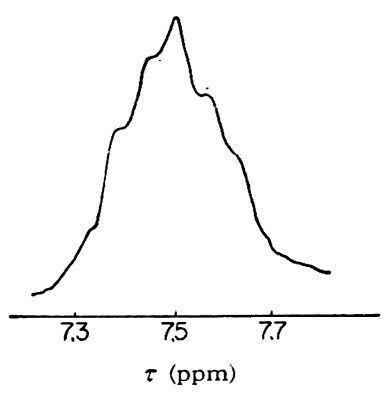

Fig. 6. Methylenic proton resonance spectrum of PAN prepared by $\mathrm{Mg}$ molecular beam method (Polymer $\mathrm{K}$ ) at $60 \mathrm{Mc}$.

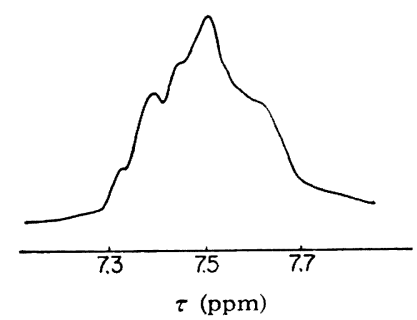

Fig. 7. Methylenic proton resonance spectrum of PAN prepared by $\gamma$-irradiation in solid state (Polymer L) at $60 \mathrm{Mc}$.

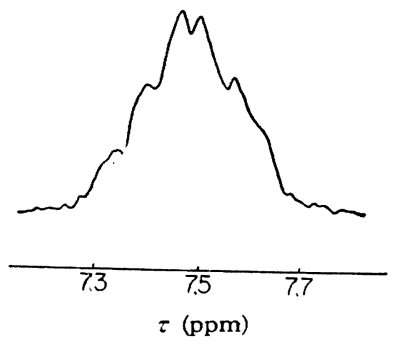

Fig. 8. Methylenic proton resonance spectrum of PAN prepared by $\gamma$-irradiation on urea-AN canal complex (Polymer N) at $60 \mathrm{Mc}$.

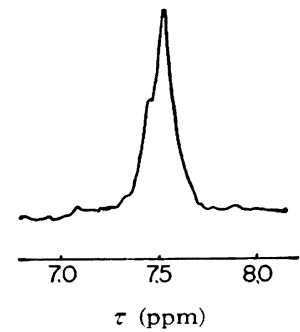

Fig. 9. Methylenic proton resonance spectrum of PAN- $\alpha d_{1}$ prepared with radical catalyst (Polymer C) at $60 \mathrm{Mc}$.

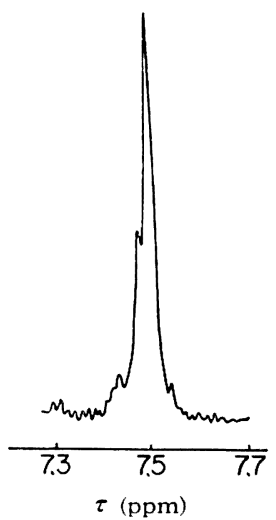

Fig. 10. Methylenic proton resonance spectrum of PAN- $\alpha d_{1}$ prepared with radical catalyst (Polymer C) at $100 \mathrm{Mc}$.

Fig. 12 には, Polymer $\mathrm{A}_{2}$ を $\left(\mathrm{CD}_{3}\right)_{2} \mathrm{SO}$ を溶媒とし て, $160^{\circ} \mathrm{C}, 60 \mathrm{Mc}$ で測定したスペクトルを示す。この スペクトルの $\mathrm{CH}_{2}$ 基プロトンの吸収には, NaCNS$\mathrm{D}_{2} \mathrm{O}$ 溶液を溶媒として測定したときのような微細な分 離が現われていない。この点については，別の機会にモ デル化合物に関する実験 ${ }^{24)}$ と比較して考察を行なう予定 である。 


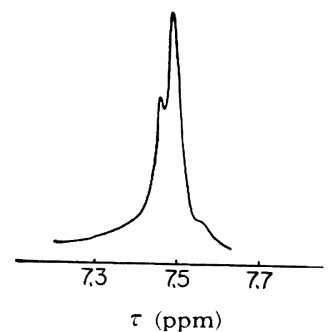

Fig. 11. Methylenic proton resonance spectrum of PAN (Polymer $A_{1}$ ) decoupled from methine proton at $100 \mathrm{Mc}(w=98 \mathrm{cps})$.

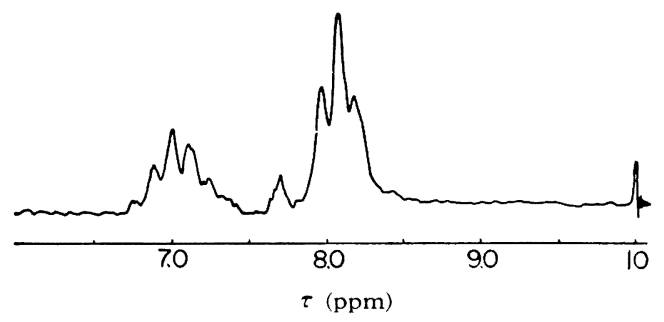

Fig. 12. NMR spectrum of PAN prepared with redox catalyst (Polymer $\mathrm{A}_{1}$ ) in $\left(\mathrm{CD}_{3}\right)_{2} \mathrm{SO}$ at $60 \mathrm{Mc}$.

\section{4. 考察}

\section{1 メチレン基共鳴}

PAN の NMR スペクトルは Fig. 1 に示すよらに, 高磁場側（ $\tau=7.5 \mathrm{ppm}$ 付近）にメチレン基プロトンに基 く共鳴吸収, 低磁場側 $(==6.5 \mathrm{ppm}$ 付近)にメチン基プ ロトンに基く共鳴吸収が現われる。他のビニルポリマー のマペクトルと同様にメチレン基共鳴吸収は Isotactic$\mathrm{CH}_{2}$ と Syndiotatic- $\mathrm{CH}_{2}$ に基く吸収の重なりであり, メチン基吸収は Isotactic- $\mathrm{CH}$, Syndiotactic- $\mathrm{CH}$, およ ぴ Heterotactic-CH に基く吸收の重なりであると考え られる。

メチレン基共鳴について, Syndiotactic- $\mathrm{CH}_{2}$ の 2 個 のプロトンは磁気的に等価であり, そのスペクトルは, $\mathrm{A}_{2} \mathrm{~B}_{2}$ 系により $1: 2: 1$ の強度比を有する Triplet して解析される。しかし, Isotactic- $\mathrm{CH}_{2}$ の 2 個のプロ トンは原理的には非等価であり, $\mathrm{A} \mathrm{B} \mathrm{C} 2$ 系による複 雑なスペクトル形が考えられる。この点は PVCについ て詳細な検討が行なわれ，Johnsen ${ }^{15)}$ は Isotactic- $\mathrm{CH}_{2}$ も等価として解析し，Tincher ${ }^{16)}$ はこれを非等俩とし た。しかし，モデル化合物での解析の結果，二量体モデ ルは非等価として解析されるが ${ }^{17), 18)}$,三量体モデルでは 等価とされ ${ }^{19), 20)}$, さらにポリマーの二重共鳴の結果から は, ポリマーについても等価として解析しうることがわ

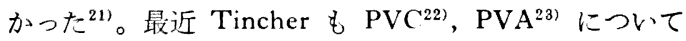

等価としての解析を行なっている。

PAN の NMR スペクトルにおけるメチレン基の共 鳴吸収には 6 個のピークが認められ, メチン基を decouple すると Fig. 11 に見られるよらに 2 個のピーク になる。また， $\alpha$ 位を重水素化した PAN のスペクトル (Fig. 9 および Fig. 10) も同様に 2 個のピークを示し ている。このことから PAN \& PVC と同様, 近似的に は Isotactic- $\mathrm{CH}_{2}$ を等価として解析しうると考えられ る。

したがって, PAN のメチレン基プロトンによる共鳴 吸収は， $\tau=7.50 \mathrm{ppm}$ に中心を有する Triplet と， $\tau=$ $7.45 \mathrm{ppm}$ に中心を有寸る Triplet との重なりであると

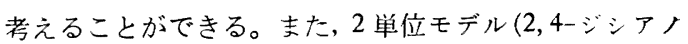
ペンタン)の NMR スペタトルの解析 ${ }^{24)}$ から見て, 他の ビニルポリマーと同様, 高磁場側が Syndiotactic- $\mathrm{CH}_{2}$, 低磁場側が Isotactic- $\mathrm{CH}_{2}$ によるものと解釈される。そ こで, これら二つの Triplet の面積比から Syndiotactic 部分と Isotactic 部分のだいたいの比率を求めることが 可能である。

\section{2 二つの Triplet の重ね合わせ}

各ピークの形が Lorentz 曲線に従うと仮定して半值 幅, Coupling constant に適当な值を用い, かつ二つの Triplet の面積比 (Syndiotactic- $\mathrm{CH}_{2}$ と Isotactic- $\mathrm{CH}_{2}$ との比)を変化させるときに, 奉測のスペクトルにほぼー 致する曲楾を得るか否かを検討した。

Lorentz の曲線に従う 1 個のピーク (Singlet) につい $\tau$, chemical shift $\tau$ に扔ける吸収強度 $D(\tau)$ は,

$$
D(\tau)=\frac{b^{2} D_{m}}{b^{2}+\left(\tau-\tau_{0}\right)^{2}}
$$

で表わされる。ここで

\section{$b:$ 半值幅の $1 / 2$}

$\tau_{0}$ : 強度最大のときの chemical shift

$D_{m}$ : chemical shift

を示す。

PAN のメチレン基フロトンによる共鳴吸収を 6 個の ピークの重ね合わせと考えると, chemical shift てにお ける全体の吸収強度 $D(\Xi)$ s は次式で示される。

$$
D(\tau)_{s}=\sum_{i=1}^{6} \frac{b^{2} D_{m i}}{b^{2}+\left(\tau-\tau_{0 i}\right)^{2}}
$$

ここで添字 $i$ は 6 個の吸収に低磁場側からつけた番号 を示す。したがって, 二つの Triplet については,

$$
D_{m 1}: D_{m 3}: D_{m 5}=1: 2: 1
$$

(Isotactic- $\mathrm{CH}_{2}$ ) 


$$
D_{m 2}: D_{m 4}: D_{m 6}=1: 2: 1
$$

(Syndiotactic- $\mathrm{CH}_{2}$ )

$$
\begin{aligned}
& \tau_{03}-\tau_{01}=\tau_{05}-\tau_{03} \\
& \tau_{04}-\tau_{02}=\tau_{06}-\tau_{04}
\end{aligned}
$$

\section{といら条件がある。}

実測スペクトルのうち, 最も分離の良いFig. 1 につい て, これに最も近い曲線を得るような $b, \tau_{0 i}$ および $D_{m 2 n+1}: D_{m 2 n+2}(n=0,1,2)$ を求めてみた。 $b$ は 0.01 から 0.06 まで 0.005 おきに， $\tau_{0 i}$ は $0.01 \mathrm{ppm}$ おき に, また, Isotactic- $\mathrm{CH}_{2}$ と Syndiotactic- $\mathrm{CH}_{2}$ の比は $5 \%$ おきに変化させて検討した結果,

$$
\begin{aligned}
& b=0.025 \\
& \tau_{01}=7.33 \mathrm{ppm}, \quad \tau_{02}=7.39 \mathrm{ppm} \\
& \tau_{03}=7.45 \mathrm{ppm}, \quad \tau_{04}=7.50 \mathrm{ppm} \\
& \tau_{05}=7.57 \mathrm{ppm}, \quad \tau_{06}=7.61 \mathrm{ppm} \\
& D_{m 2 n+1}: D_{m 2 n+2}=25: 75
\end{aligned}
$$

においてほほほFig. 1 の実測スペクトルに近い曲線 (Fig. 13)を得ることができさ。したがって, Coupling constant の值は

$$
\begin{aligned}
\text { Isotactic- } \mathrm{CH}_{2}: & J_{\mathrm{CH}-\mathrm{CH}_{2}}=7.2 \mathrm{cps} \\
\text { Syndiotactic- } \mathrm{CH}_{2}: & J_{\mathrm{CH}-\mathrm{CH}_{2}}=6.6 \mathrm{cps}
\end{aligned}
$$

と考えられる。

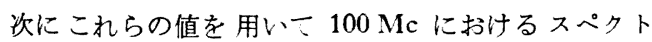
ルを合成した場合，実測に近い曲線を得るか否かを見る と, Fig. 14-b に示すごと?,実測スペクトル Fig. 14-a とほぼ一致する曲線を得るので, 上記の Coupling constant の值はだいたい妥当な⿻コ一考えられる。ただし， この場合の半值幅は 0.02 とした。

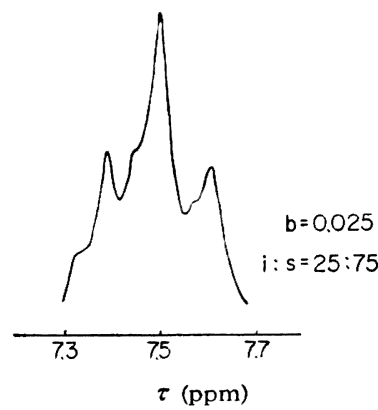

Fig. 13. Calculated methylenic proton resonance spectrum of PAN at $60 \mathrm{Mc}$ assuming $75 \%$ syndiotactic and $25 \%$ isotactic diads. (a)

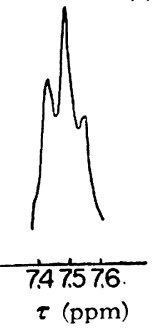

Fig. 14-a. Methylenic proton resonance spectrum of PAN prepared with redox catalyst (Polymer $\left.\mathrm{A}_{1}\right)$ at $100 \mathrm{Mc}$.

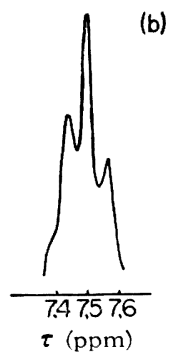

Fig. 14-b. Calculated methylenic proton resonance spectrum of PAN at $100 \mathrm{Mc}$ assuming $75 \%$ syndiotactic and $25 \%$ isotactic diads.

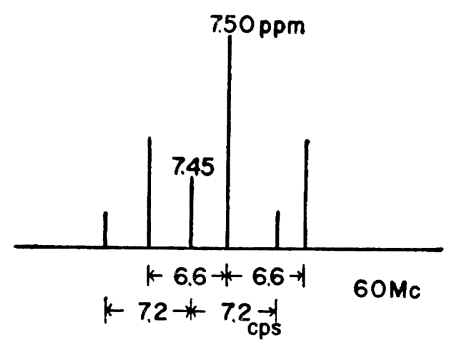

Fig. 15. Coupling constants and chemical shifts of methylenic protons of PAN at $60 \mathrm{Mc}$.

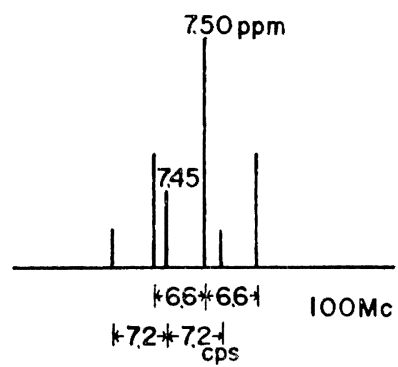

Fig. 16. Coupling constants and chemical shifts of methylenic protons of PAN at $100 \mathrm{Mc}$. 
Fig. 15 およぴ Fig. 16 に $60 \mathrm{Mc}$ および 100Mc に おけるメチレン基プロトンの吸収ピークの位置を図式的 に表示した。

\subsection{Syndiotactic 部分と Isotactic 部分の比}

前記の chemical shift および coupling constant の 值を用いて $D_{m 2 n+1}: D_{m 2 n+2}$, すなわち, Isotactic- $\mathrm{CH}_{2}$ : Syndiotactic- $\mathrm{CH}_{2}$ の比率を変えて $60 \mathrm{Mc}$ のス゚クト ルを計算によって求めてみる。

Polymer $A_{1}$ は他の試料に比べて重合度が低くスペク

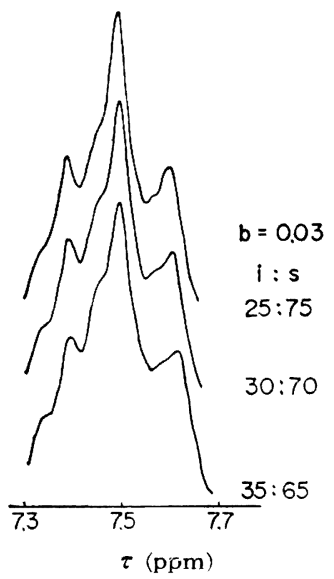

Fig. 17-a. Calculated methylenic proton resonance spectrum of PAN at $60 \mathrm{Mc}(\mathrm{I})$.

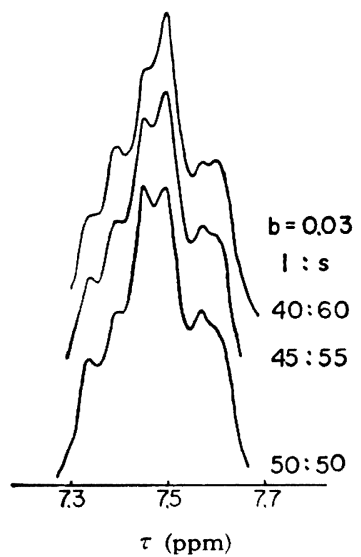

Fig. 17-b. Calculated methylenic proton resonance spectrum of PAN at $60 \mathrm{Mc}$ (II).

トルの分傩が良好で， $b=0.025$ を仮定した計算値上良 く一致したが, Polymer $\mathrm{A}_{2} \sim$ Polymer $\mathrm{P}$ については $b$ $=0.03$ とすると, 実測值にほぼ近い形のスペクトルが得 られる。 $b=0.03$ として $D_{m 2 n+1}: D_{m 2 n+2}=25: 75,30$ : $70,35: 65,40: 60,45: 55$ および $50: 50$ の場合につ
いて計算した $60 \mathrm{Mc}$ のスペクトルを Fig. 17-a，bに 示す。以上の計算により得られた 6 個のスペクトルに ついて $\tau_{08}$ と $\tau_{04}$ における $D(\tau)_{s}$ の比を求め, これを $D_{m 2 n+1}: D_{m 2 n+2}$ に対してプロットすると, Fig. 18 の 曲線が得られる。この線を用いて実測スペクトルにお ける $7.45 \mathrm{ppm}$ と $7.50 \mathrm{ppm}$ の強度比から大約の Isotactic 部分と Syndiotactic 部分の比を求めることがで きる。

各試料は精製が困難であり，かつ半值幅を一定にする

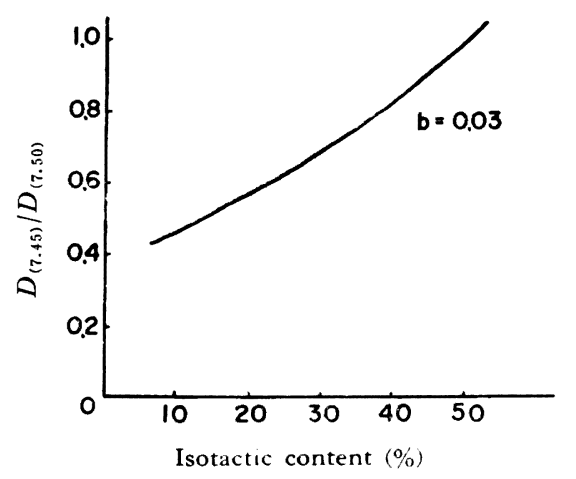

Fig. 18. Relationship between isotactic content and intensity ratio at 7.45 to $7.50 \mathrm{ppm}$.

ことも測定技術上困難であって，実測スペクトルと計算 との一致は必ずしも十分とはいえないが，16 種類の試 料について求めた Syndiotactic 部分と Isotactic 部分の だいたいの比率は Table 2 に示すとおりである。

\section{4 重合方法による立体規則度の差}

上に述べた方法によって，PAN の立体規則度に関し て彷来の方法では得られなかった新しい知見を得ること ができた。なお，詳細な議論は $\mathrm{CH}$ 基共鳴の解析にま た㸚ばならないが, 現在までに得られた種々の重合方法 による PAN は，ほとんど Syndiotactic 部分が多いこ とがわかった。ラジカル重合, 常温に拈けるアニオン重 合では Syndiotactic 部分が約 $3 / 4$ を占めるが, 低温の アニオン重合では Isotactic 部分が増加する傾向が認め られる。

促来, 立体規則性の PAN 在得たという報告がある。 低淹固相放射線重合 ${ }^{12)}, \mathrm{Mg}$ イオンによる分子線法 ${ }^{11)}$, おう よび尿素包接化合物の放射線重合 ${ }^{18), 14)}$ によって得られ る PAN についても NMR スペクトルから検討したが, 低温放射線重合, 分子線法によるものはアニオン重合と ほぼ同程度であり，尿素包接化合物によるものは，Isotactic 部分がさらに多いものであって，いずれも顕著な 立体特異性を示していない。

しかしながら，以上の結果はメチレン基共鳴の解析の みによるものであり, 今後, さらにメチン基共鳴の解析 
Table 2. Tacticity of PAN approximately estimated from methylenic resonance.

\begin{tabular}{|c|c|c|c|c|}
\hline \multicolumn{2}{|c|}{ Polymer } & \multirow{2}{*}{$\frac{\text { Polymerization meîhod }}{\text { Radical (redox) }}$} & \multirow{2}{*}{$\frac{\begin{array}{c}\text { Syndiotactic- } \mathrm{CH}_{2} \\
(\%)\end{array}}{75}$} & \multirow{2}{*}{$\frac{\begin{array}{c}\text { Isotactic- } \mathrm{CH} \\
(\%)\end{array}}{25}$} \\
\hline$A_{1}$ & PAN & & & \\
\hline $\mathbf{A}_{2}$ & PAN & Radical (redox & 75 & 25 \\
\hline $\mathrm{B}$ & PAN & Radical & 75 & 25 \\
\hline $\mathrm{C}$ & $\mathrm{PAN}-\alpha d_{1}$ & Radical & 75 & 25 \\
\hline $\mathrm{D}$ & PAN & Arionic & 75 & 25 \\
\hline $\mathrm{E}$ & PAN & Anionic & 75 & 25 \\
\hline $\mathrm{F}$ & PAN & Anionic & 65 & 35 \\
\hline G & PAX & Anionic & 60 & 40 \\
\hline $\mathrm{H}$ & PAN & Anionic & 60 & 40 \\
\hline I & PAX & Anionic & 55 & 45 \\
\hline $\mathrm{J}$ & PAN & Anionic & 55 & 45 \\
\hline $\mathrm{K}$ & PAN & Molecular beam & 60 & 40 \\
\hline $\mathrm{L}$ & PAN & Irradiation in solid state & 65 & 35 \\
\hline M & $\operatorname{PAN}-\alpha d_{1}$ & Irradiation in solid state & 65 & 35 \\
\hline $\mathrm{N}$ & PAN & Irradiation on urea canal & 50 & 50 \\
\hline $\mathrm{O}$ & $\mathrm{PAN}-\alpha d_{1}$ & Irradiation on urea canal & 50 & 50 \\
\hline$P$ & PAN & Irradiation on urea canal & 55 & 45 \\
\hline
\end{tabular}

による Heterotactic を含む立体規則度の決定と, その 結果に基いて赤外スペクトル, X 線回折など固体構造の 面での再検討が必要と考えられる。

付 記：本研究に関しご指導を賜わった大阪大学田所宏行教 授，小林雅通氏，および試料の一部の提供をいたたいた京都大 学林晃一郎助教授,ならびに発表を許可された当社緎維技術研 究所長森本佐一取䋨役深く感謝する。なお, 本研究の一部は 第 14 回高分子討論会 (1965 年 10 月, 京都) で報告した。また, 本穆の投稿後, PAN の $\left(\mathrm{CD}_{3}\right)_{2} \mathrm{SO}$ 溶液の NMR について下 記の報告が出されている。

K. Matsuzaki, T. Uryu, K. Ishıgure, M. Takeuchi J. Polymer Sci., B4, 93 (1966)

\section{文献}

1) C. R. Bohn, J. R. Schaefgen, W. O. Statton J. Polymer Sci., 55, 531 (1961)

2) P. H. Lindenmeyer, R. Hosemann: J. Appl. Phys., 34, 42(1963)

3) H. Tadokoro, S. Murahashi, R. Yamadera, T. Kamei : J. Polymer Sci., A1, 3029(1963)

4) 山寺礼三: 高化, 21, 362(1964)

5) R. Yamadera, H. Tadokoro, S. Murahashi : J. Chem. Phys., 41, 1233(1964)

6) R. Chiang: J. Polymer Sci., A3, 2019(1965)

7) 西岡篤夫: 工化, 68, 757(1965)

8) K. Matsuzaki, T. Uryu, A. Ishida, T. Ohki :
J. Polymer Sci., B2, 1139 (1964)

9) K. Matsuzaki, T. Uryu, M. Takeuchi : J. Polymer Sci., B3, 835(1965)

10) R. Yamadera, M. Murano: J. Polymer Sci., B3, 821 (1965)

11) В. А. Каргин, В. А. Каванов, В. Л. Зувов, Л. М. Паписов : Еысокомол. Соед., 3, 426(1961)

12)田畑米穂, 石榑顕吉：化学の領域, 18, 1081 (1964)

13) J. F. Brown, D. M. White: J. Am. Chem. Soc., 82, $5671(1960)$

14）川崎元夫, 前川輝彦, 林 晃一郎, 岡村誠三：高 分子学会第 12 回年次大会 (1963 年 5 月, 東京)

15) U. Johnsen: J. Polymer Sci., 54, S6(1961)

16) W. C. Tincher: J. Polymer Sci., 62, S148(1962)

17) S. Satoh: J. Polymer Sci., A2, 5221 (1964)

18) D. Doskočilová : J. Polymer Sci., B2, 421 (19ó4)

19）安部康明, 田隅三生, 島内武彦, 佐藤至朗, 中条利 一郎, 長井栄一：第 4 回核磁気共鳴討論会 (1964 年 11 月，東京）

20) T. Shimanouchi, M. Tasumi, Y. Abe: Makromol. Chem., 86, 43(1965)

21) F. A. Bovey, E. W. Anderson, D. C. Douglass : J. Chem. Phys., 39, 1199(1963)

22) W. C. Tincher: Makromol. Chem., 85, 20(1965)

23) W. C. Tincher : Makromol. Chem., 85, 46(1965)

24）村野政生，兼石站夫，山寺礼三：第 15 回高分子 学会年次大会講演要旨集, 109 (1966) 


\title{
Studies on the Tacticity of Polyacrylonitrile by the High Resolution Nuclear Magnetic Resonance Spectrum
}

\author{
By Masao Murano* and Reizo Yamadera*
}

The nuclear magnetic resonance spectra of polyacrylonitriles prepared under various polymerization conditions were measured in $\mathrm{NaCNS}-\mathrm{D}_{2} \mathrm{O}$ solution. The methylenic proton resonance could be separated into two triplets: one is due to the protons of the syndiotactic methylene groups and the other is due to the isotactic ones. The tacticity of polyacrylonitrile could be determined by the ratio of the integrated intensities of the two triplets.

Polyacrylonitrile samples prepared with the radical catalysts have the syndiotactic part of approximately $75 \%$, and polyacrylonitriles prepared by the anionic polymerization at low temperature, $\gamma$-irradiation in solid state, $\mathrm{Mg}$ molecular beam and $\gamma$-irradiation on the urea canal complex are more isotactic but have no remarkable stereospecificity.

* Textile Research Institute, Toyo Spinning Company, Ltd. (Katata, Shiga) 